\title{
The Correlation of Myth and Symbol in D.H. Lawrence's Novels
}

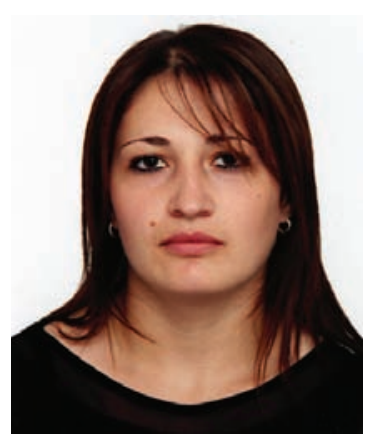

Mariana Sargsyan

$A \mathbf{S}^{\text {has already been established, the study of }}$ $A \mathbf{S}_{\text {symbolic units within the scope of a literary text }}$ is directly interrelated with the study of the author's individuality and his philosophical outlook, and, therefore, has to deal with a number of extralinguistic factors. Every writer is a bearer of unique qualities which are reflected in his original manner of writing. The individual manner of writing (within a literary text) is materialized through a specific choice of phonetic, semantic and syntactic units, linguostylistic and linguopoetic expressive means. These, on the one hand, reveal the individual traits in the writer's character, and, on the other hand, get enriched with additional overtones, expanding their preliminary semantic borders. This fact, in its turn, brings forward special correlations between form and content, in which, as usual, the form dominates, since the reader attaches more importance to the manner of presentation than to the object. Thus, in the reader's imagination, the whole system of units from phonetic, semantic and syntactic levels of the literary text brings forth concrete images that reveal the writer's psychological peculiarities, his way of thinking and his manner of reproducing the objective reality.

D.H. Lawrence's world view and his own method of reproducing the objective reality are associated with generalization and introduction of various symbolic images, which obtain additional semantic volume within the philological context of his creative work. Necessarily, the adequate perception of the latter demands a systematic approach. D.H. Lawrence, an exclusive representative of the psychological novel, introduces a special system of symbolic images and conveys the idea that the era of industrialization spreads but malice and vice upon the world, depriving human life of vital contact with nature. In his works D.H. Lawrence shows that the bourgeoisie has exhausted itself and, under such conditions, the ever-going "man - society" discordance and one's protest against the deeply rooted evils gain grounds. Therefore, great changes in social, political and economic spheres of life become imminent. All these observations are combined with thorough penetration into the very depths of human essence, man's inner world full of passions, instincts and emotions of various nature. It is exactly due to these factors that D.H.Lawrence's works undergo global philosophical transformation and become liable to versatile studies. Modern civilization, which has buried itself alive because of industrial achievements, is described as anti-social and anti-humane, as a "machine" devouring the natural essence of human beings. D.H.Lawrence criticizes modern civilization proposing his own model of recovery: "Return to natural sources, by intermingling with nature and the whole Universe, freeing instincts and, finally, the 
triumph of instincts over the Reason". ${ }^{1}$ In everyday struggle with society, a human being has to suppress his feelings, instincts and passions, and this brings to alienation. As a result, man's personality, his inner world with all the vast rainbow of feelings and boundless emotions gradually degrade.

In prehistoric times, the relationship between man and nature was quite intimate: the prehistoric man was full of emotions and prejudice, unlike his modern counterpart, whose tastes, feelings and ideas are imposed by capitalistic civilization. According to D.H.Lawrence, any living creature in nature is endowed with Anima which is even more powerful than the human being himself. That's why, in his model of world view, like in primeval religious worships, it is increasingly difficult to draw a clear line between the organic and inorganic, material and animistic essence.

Thus, in D.H.Lawrence's creative works we face the rebirth of many prehistoric mythical symbols derived from animistic religions. Natural phenomena (the sun, the sea, a flower, snow, the moon, flame, etc.) transform through the prism of the writer's imagination, thus concentrating and generalizing his observations on the possible model of further development of the society and his standpoint towards this or that phenomenon.

Myth and symbol are so closely interrelated with each other in D.H.Lawrence's works that sometimes it is not easy to distinguish between them. However, our research has brought us to the conclusion that myth serves as background for deriving symbolic images - concepts which come forth to fill the gap between the author's motive and the reader's imagination. Thus, symbolism is used as an all-round method to act upon the reader's imagination and, as D.H.Lawrence states himself, "Symbols do not mean something, but they stand for whole units of human feelings and experience". ${ }^{2}$ In this case myth serves as background which helps to achieve a deeper isight into the symbolic images. Thus, in D.H.Lawrence's imagery, a myth can be described as the final stage in the development of symbolic images. Many mythical phenomena and personages are revived in his novels and, in fact, they make part and parcel of his works. However, the most conspicuous one among them is the mythical image of the sun which plays a pivotal role reflecting the old worship of the sun as an endless source of energy.

It is not strange at all that the image of the sun gains a central role, as this fact directly results from the role of the sun itself, its place in the universe and its importance in sustaining life on the earth. "Man - nature" relationship is an ever-going process, as in everyday life man gets in touch with nature. Anyhow, the interrelation between man and the sun is of great importance, since the sun itself is a kind of universe from which one can endlessly derive wisdom, power, self-cognition and love. "The prayer to the universe", - as D.H. Lawrence insists upon, - "ends significantly with the organic sun. What we want is to destroy our false, inorganic connections with the cosmos, the sun and the earth, with mankind and nation and family. Start with the sun, and the rest will slowly, slowly happen". ${ }^{3}$

"Sun" and "The Woman Who Rode Away" reflect the mythical image of the sun most explicitly, though D.H.Lawrence's contradicting, or even dualistic principles retain their validity in reflecting the old myths about the sun. 
In "Sun", with the introduction of the image of the sun in the title of the novel, the author underlines its central role. In this story this image reflects the old belief of the sun as an endless source of energy and a great healer of human souls:

Again a morning when the sun lifted himself naked and molten, sparkling over the sea's rim. The house faced south-west.

Juliet lay in her bed and watched his rise. It was as if she had never seen the sun rise before. They had never seen the naked sun stand up pure upon the sea line, shaking the night off himself.

So the desire sprang secretly in her to go naked in the sun.

She cherished her desire like a secret.

(“Sun”, p.342)

In the above mentioned context, we see Juliet who, desiring to come into close contact with nature, fleeds away from the society. At first, she finds this contact quite unexpected and thrilling, but, suddenly, her relationship with the sun becomes intimate. She is lying naked, laughing to herself, with a flower in her navel. Juliet cannot even imagine how she has lived in town full of dust and it is just enough for her to see the naked sun rise in the sky to feel and be overpowered with its healing energy. At first glance her behavior may seem somewhat odd to the reader. Anyhow, reading between the lines, we feel the author's great sympathy for those who lack vital connections with nature.

People have gone too far and have alienated themselves from the sun, i.e. from nature, but, in fact, "man - nature" relationship should be the only existing reality. Thus, Juliet proceeds with her contact with the sun, getting closer to the Universe.

Every day, in the morning towards noon, she lay at the foot of the powerful, silverpawed cypress tree, while the sun rode jovial in heaven. By now she knew the sun in every thread of her body, there was not a cold shadow left.

And her heart, that anxious straining heart, had disappeared altogether, like a flower that falls in the sun, and leaves a ripe seed-case.

$$
\text { ("Sun", p. 345) }
$$

Juliet awakens emotionally in the elemental presence of the sun, she feels the greatest sun through all her body, every little breathing cell in her becomes filled with the healing energy of the sun. Thus, her soul and mind are directed to the endless universe and she is ready for new germination.

One of the typical peculiarities of any mythical object or phenomenon (which finds its reflection in symbolic images) is personification. In ancient times myth dominated men's thought, as it was believed that any object or natural phenomenon had its soul and power and that life wholly depended on their will. It is exactly for this reason that D.H.Lawrence refers to the sun as a phenomenon of masculine gender (he, himself, him) underlying its almighty power. "Sun - woman" relationship is like "man - woman" 
relationship, as in prehistoric times the sun symbolized male essence. Thus, in this novel the image of the sun symbolizes vitality as a source of life.

We observe a different symbolic image of the sun in "The Woman Who Rode Away". Here we come across with traces of Indian (Aztec) Savagery of sacrifice, an almighty power which constantly demands sacrifice for the vices committed on the Earth or as a manifestation of veneration. With the introduction of a consistent system of images, the author accentuates the ever-going vices upon the earth and nature, with the sun at its head, is hostile towards people since they have lost their touch with the latter.

'I came away from the white man's God myself. I came to look for the God of the Chilchui'.

'Does the white woman seek the gods of the Chilchui because she is weary of her own God?' came the question.

'Yes, she does. She is tired of the white man's God', she replied, thinking that was what they wanted her to say. She would like to serve the gods of Chilchui.

("The Woman Who Rode Away", p. 345)

Juliet's behavior ("Sun") is similar to that of the woman who rode away. They both have fled away from the existing reality in search of a new reality, new God, hoping to find the true meaning of existence. In the philological context of these works, the image of the sun is perceived as a means of gaining freedom, and creating a new mode of life, where there are no individuals, and the only reality that matters is the relation between man and nature.

We have lost our power over the sun, and we are trying to get him back. But he's wild with us, and shy like a horse that has got away. We have to go through a lot.

("The Woman Who Rode Away", p. 330)

D.H. Lawrence himself worshipped nature. The living nature, its powerful energy and its activity are contrasted to the man's life full of conventionality and restrictions imposed by modern civilization. So, the sun is "wild" with people, and with the introduction of the image of the "wild" sun (he's wild), the writer imparts to the reader his own attitude towards people who have alienated themselves from nature.

However, this situation finds its solution. The woman who rode away is sacrificed to the Gods of Chilchui. D.H.Lawrence reserves death and consummation for those who lack vital connections. The ritual of sacrifice itself carries a symbolic meaning, as, according to ancient tradition, the "blue" color in which the woman is dressed, symbolizes death, exhaustion of vital powers. Nevertheless, the ritual of sacrifice presupposes rebirth and resurrection. "Departure and return, the pattern of most ancient myths, became D.H.Lawrence's formula". ${ }^{3}$

Thus, within the context of the above-mentioned two stories, we observe the symbolic image of the sun, the nature of which becomes polarized due to the reflection of opposite mythological realities. It is an evident fact that the dualistic structure of 
D.H.Lawrence's system of images has long been a question of acute debates and contradictory arguments. It is, perhaps, for this reason that his works have not got consistent estimation in the circle of literary critics and D.H.Lawrence's contribution to the development of novel has been belittled. However, in D.H.Lawrence's creative works the symbolic images play a most important role in generalizing the objective reality. The symbolic image of the sun is not only an ideological but also an expressive unit. Hence, having been revealed through the symbol, the myth tends to become more than philosophy, more than mere art. It is striking to observe how organically the symbolic image of the sun gets intermingled with the whole system of images which are enriched with allegorical overtones, thus becoming one of the basic means of realistic generalization. D.H.Lawrence conveys not only the idea of vagueness of the reality but also reveals its ever-going, moving essence, and the symbol becomes a good means of conveying this ever changing particularity of the reality.

\section{References:}

1. Modern Masters: D.H.Lawrence. / Ed. by Frank Kermode. New York, 1978.

2. The Later D.H.Lawrence. New York, 1952.

3. Lawrence D.H. Phoenix: The Posthumous Papers of D.H.Lawrence. New York: Viking, 1964.

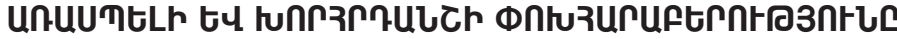

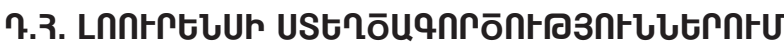

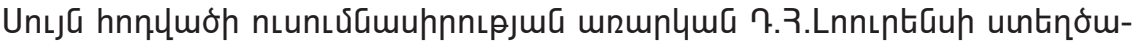

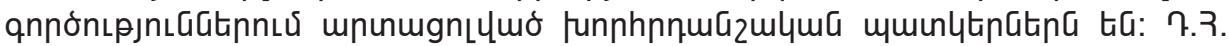

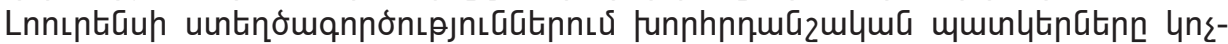

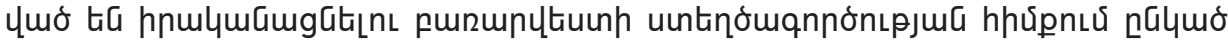

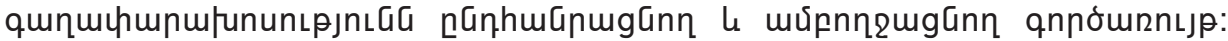

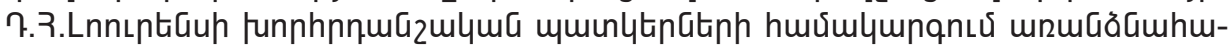

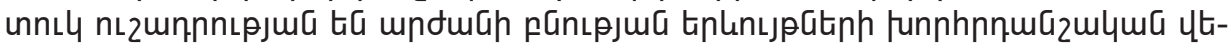

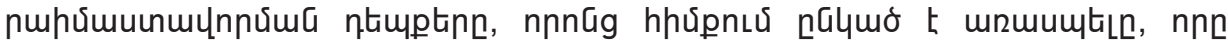

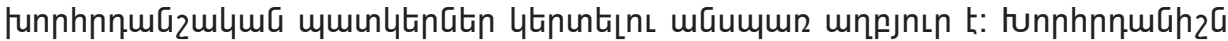

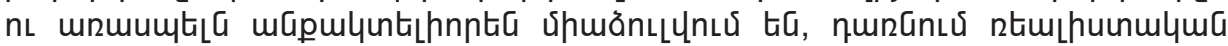

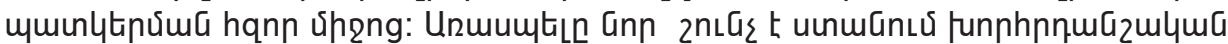

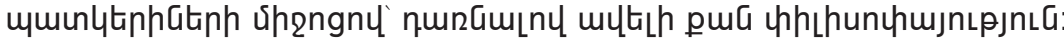

